\title{
Koordynacja zabezpieczenia
} społecznego w Unii Europejskiej

\author{
The Coordination of Social Security \\ in the European Union
}

Streszczenie. Tematem artykułu są najistotniejsze zagadnienia z zakresu koordynacji zabezpieczenia społecznego w UE oraz regulacje prawa unijnego dotyczące składek na ubezpieczenia społeczne. Prawo UE określa fundamentalne zasady koordynacji zabezpieczenia społecznego w UE, które zawierają gwarancję ochrony praw osób przemieszczających się pomiędzy państwami członkowskimi UE. Zasady koordynacji zabezpieczenia społecznego mają normatywny charakter tj. są ujęte w unijnym systemie przepisów prawnych. Do najważniejszych zasad należy: zasada równego traktowania, zasada stosowania jednego ustawodawstwa, zasada przeciwdziałania kumulacji świadczeń (proporcjonalności), zasada pierwszeństwa w przypadku zbiegu praw do świadczeń. Regulacje prawa unijnego dotyczące składek na ubezpieczenie społeczne nie zastępują ustawodawstwa krajowego, a jedynie je uzupełniają na poziomie Wspólnoty w celu zapewnienia ściślejszej współpracy pomiędzy instytucjami zajmującymi się zabezpieczeniem społecznym. 
Alicja Młynarczyk

Słowa kluczowe: ochrona obywateli przed utratą ich praw w dziedzinie zabezpieczenia społecznego; koordynacja zabezpieczenia społecznego w UE; regulacje prawa unijnego dotyczące składek na ubezpieczenia społeczne.

\begin{abstract}
The topic of the paper refers to the most crucial issues related to the coordination of social security in EU and the regulations of the European Union law related to the national insurance contributions. The EU law determines fundamental principles for the coordination of social security in EU, which include a warranty for the protection of rights related to persons moving between the European Union Member States. The principles of the coordination of social security have normative nature, i.e. they are included in the European Union system of legal provisions. The most important principles are: the principle of equal treatment, the principle of the application of single legislation, the principle of counteracting a cumulation of benefits (proportionality), the principle of priority in the case of converging rights to benefits. The European Union legal regulations related to the national insurance contributions do not replace the national legislation but only supplement it at the level of the Community so as to ensure a closer cooperation between the institutions, which handle social security.
\end{abstract}

Keywords: protection of nationals against the loss of their rights in the field of social security; coordination of social security in EU; European Union legal regulations related to national insurance contributions.

\title{
1. Wstęp
}

System koordynacji zabezpieczenia społecznego w Unii Europejskiej tworzy zespół norm prawnych należących do prawa unijnego ustalającego fundamentalne zasady w tej dziedzinie, które zawierają gwarancję ochrony praw osób korzystających z możliwości swobodnego podróżowania i pobytu na terytorium państw członkowskich. Przepisy Unii Europejskiej dotyczące zabezpieczenia społecznego określają obowiązujące w tej dziedzinie prawa i obowiązki i odnoszą się do wszystkich osób przemieszczających się między państwami członkowskimi UE. Założeniem tego prawa nie jest harmonizacja krajowych systemów zabezpieczenia społecznego, ale ochrona obywateli przed utratą ich praw w dziedzinie zabezpieczenia 
społecznego ${ }^{1}$. Przepisy UE z omawianego zakresu nie unieważniają ustawodawstwa krajowego ${ }^{2}$. Do ustawodawcy narodowego należy określenie m.in.: kto podlega obowiązkowemu ubezpieczeniu społecznemu, jaki zakres świadczeń jest objęty tym ubezpieczeniem, w jakiej wysokości i na jakich warunkach powinny być opłacane składki na ubezpieczenie społeczne. Składki na ubezpieczenie społeczne są istotnym elementem systemu koordynacji zabezpieczenia społecznego w UE, gdyż ich opłacenie jest podstawowym obowiązkiem ubezpieczonego ${ }^{3}$.

\section{Pojęcie i najważniejsze cechy zasad koordynacji zabezpieczenia społecznego}

Zasady koordynacji zabezpieczenia społecznego mają normatywny charakter, tj. są ujęte w systemie unijnych przepisów prawnych. Ich szczególna rola polega na określeniu ponadnarodowych wartości w dziedzinie ochrony praw z zakresu zabezpieczenia społecznego. Istotne zasady koordynacji systemów zabezpieczenia społecznego ustanawia rozporządzenie Parlamentu Europejskiego i Rady (UE) nr 883/2004 z dnia 29 kwietnia 2004 r. ${ }^{4}$ Podstawową zasadą w ramach takiej koordynacji jest zasada równego traktowania zainteresowanych osób na podstawie różnych ustawodawstw krajowych. Równość traktowania wszystkich osób pracujących ma zapewnić zasada stosowania jednego ustawodawstwa, zgodnie z którą

1 Zob. również: J. Wantoch-Rekowski, System ubezpieczeń społecznych a budżet państwa. Studium prawnofinansowe, Warszawa 2014, s. 41 i n.

2 Przepisy UE $w$ dziedzinie zabezpieczenia społecznego. Twoje prawa w innych państwach Unii Europejskiej, Urząd Publikacji Unii Europejskiej, Luksemburg 2010, s. 3.

3 Zob. także np.: D. Dzienisiuk, Zabezpieczenie społeczne w Unii Europejskiej - koordynacja świadczeń, Warszawa 2004; T. Major (red.), B. Pawłowska, Ubezpieczenie społeczne migrujqcych pracowników oraz osób prowadzq̨cych działalność gospodarczq, Warszawa 2004; G. Uścińska, Kierunki rozwoju świadczeń z zabezpieczenia społecznego na przykładzie wspólnotowej koordynacji [w:] A. Patulski, K. Walczak (red.), Jedność w różnorodności. Studia z zakresu prawa pracy, zabezpieczenia społecznego i polityki społecznej. Księga pamiqtkowa dedykowana profesorowi Wojciechowi Muszalskiemu, Warszawa 2009, s. 331 i n.

4 Rozporządzenie Parlamentu Europejskiego i Rady (UE) nr 883/2004 z dnia 29 kwietnia 2004 r. w sprawie koordynacji systemów zabezpieczenia społecznego (Dz.Urz. UE L 200 z 7 czerwca 2004 r.). 
są stosowane przepisy z zakresu zabezpieczenia społecznego tego państwa członkowskiego, w którym dana osoba pracuje jako pracownik najemny lub na własny rachunek. Zasada proporcjonalności nakazuje uwzględnianie okoliczności lub wydarzeń w taki sposób, aby nie prowadziło to do obiektywnie nieuzasadnionych rezultatów, ani do kumulacji świadczeń tego samego rodzaju za ten sam okres. Zasady koordynacji zasad gwarantują, że osoby przemieszczające się we Wspólnocie i osoby pozostające na ich utrzymaniu zachowują nabyte już prawa i korzyści oraz te, które są w trakcie nabywania. Powyższe cele powinny być osiągnięte w szczególności poprzez sumowanie wszystkich okresów ubezpieczenia uzyskanych ma mocy ustawodawstw różnych krajów. Parlament Europejski i Rada (UE) stwierdzają, że niezbędne jest objęcie osób przemieszczających się we Wspólnocie systemem zabezpieczenia społecznego tylko jednego państwa członkowskiego, aby uniknąć nałożenia się przepisów różnych krajów członkowskich oraz wynikających z tego tytułu komplikacji. Według zdania Parlamentu Europejskiego i Rady (UE) prawa dotyczące zabezpieczenia społecznego nie powinny być uzależnione od miejsca zamieszkania zainteresowanych osób, jednakże w szczególnych przypadkach, zwłaszcza odnoszących się do świadczeń socjalnych, miejsce zamieszkania może być brane pod uwagę.

\section{Zasada równego traktowania}

Zasada równego traktowania została wyrażona w art. 4 rozporządzenia Parlamentu Europejskiego i Rady (UE) nr 883/2004, na mocy którego osoby podlegające powyższemu rozporządzeniu korzystają z tych samych świadczeń i podlegają tym samym obowiązkom, co obywatele każdego państwa członkowskiego. Zakres podmiotowy omawianego rozporządzenia obejmuje obywateli państwa członkowskiego, bezpaństwowców i uchodźców mieszkających w państwie członkowskim, którzy podlegają lub podlegali ustawodawstwu jednego lub kilku państw członkowskich oraz obejmuje członków ich rodzin, a także członków rodzin osób zmarłych, które podlegały ustawodawstwu jednego lub kilku państw członkowskich, niezależnie od obywatelstwa tych osób, o ile są obywa- 
telami jednego z państw członkowskich lub bezpaństwowcami lub uchodźcami zamieszkałymi na terytorium jednego z państw członkowskich.

Zakres zasady równego traktowania jest szeroki i odnosi się do równego traktowania świadczeń, dochodów, okoliczności oraz zdarzeń. Przepisy UE w zakresie koordynacji systemów zabezpieczenia społecznego dotyczą następujących rodzajów świadczeń: z tytułu choroby, macierzyństwa, wypadków przy pracy, chorób zawodowych, z tytułu inwalidztwa, emerytur, rent rodzinnych, z tytułu śmierci, świadczeń dla bezrobotnych, świadczeń rodzinnych, przedemerytalnych. Zasada równego traktowania i niedyskryminacji ma fundamentalne znaczenie w ramach przepisów koordynujących. Mówi o niej art. 5 rozporządzenia Parlamentu Europejskiego i Rady (UE) nr 883/2004 ze zmianami wprowadzonymi rozporządzeniem Parlamentu Europejskiego i Rady (UE) nr 988/20095 , który nakazuje zastosowanie odpowiednich przepisów ustawodawstwa właściwego państwa członkowskiego, także do otrzymanych świadczeń równoważnych nabytych na podstawie prawodawstwa innego państwa członkowskiego. Natomiast w przypadkach, w których na podstawie ustawodawstwa właściwego państwa członkowskiego, zaistnieniu pewnych okoliczności lub zdarzeń, przypisywane są określone skutki prawne, to państwo członkowskie uwzględnia podobne okoliczności lub zdarzenia zaistniałe w każdym państwie członkowskim tak, jak gdyby miały one miejsce na jego własnym terytorium. Zasada równego traktowania zaleca sumowanie okresów ubezpieczenia spełnionych na podstawie ustawodawstwa każdego innego państwa członkowskiego, tak jakby były to okresy spełnione na podstawie ustawodawstwa danego państwa.

\section{Zasada stosowania jednego ustawodawstwa}

Właściwe funkcjonowanie zasady równego traktowania ma zapewnić zasada stosowania jednego ustawodawstwa. Precyzują ją przepisy

5 Rozporządzenie Parlamentu Europejskiego i Rady (WE) nr 988/2009 z dnia 16 września 2009 r. zmieniające rozporządzenie (WE) nr 883/2004 w sprawie koordynacji systemów zabezpieczenia społecznego oraz określające treść załączników (Dz.Urz. UE L 284 z 30 października 2009 r.). 
wskazujące ustawodawstwo państwa członkowskiego mające zastosowanie do osoby ubezpieczonej. Regułą jest stosowanie ustawodawstwa tylko jednego państwa członkowskiego. Na mocy art. 13 wymienionego wyżej rozporządzenia osoba, która wykonuje pracę najemną w dwóch lub kilku państwach członkowskich, podlega:

- ustawodawstwu państwa członkowskiego, w którym ma miejsce zamieszkania, jeżeli wykonuje znaczną część pracy w tym państwie członkowskim lub jeżeli jest zatrudniona przez różne przedsiębiorstwa lub przez różnych przedsiębiorców, którzy mają siedzibę albo miejsce wykonywania działalności w różnych państwach członkowskich,

- ustawodawstwu państwa członkowskiego, w którym znajduje się siedziba lub miejsce wykonywania działalności zatrudniającego ją przedsiębiorstwa, czy też pracodawcy, jeżeli osoba ta nie wykonuje znacznej części swej pracy w państwie członkowskim, w którym ma miejsce zamieszkania.

Osoba, która wykonuje pracę na własny rachunek w dwóch lub w kilku państwach członkowskich, podlega:

- ustawodawstwu państwa członkowskiego, w którym ma miejsce zamieszkania, jeżeli wykonuje znaczną część pracy w tym państwie członkowskim, lub

- ustawodawstwu państwa członkowskiego, w którym znajduje się centrum zainteresowania dla jej działalności, jeżeli osoba ta nie zamieszkuje w jednym z państw członkowskich, w którym wykonuje ona znaczną część swej pracy.

Istotnym zagadnieniem $\mathrm{w}$ ramach koordynacji zabezpieczenia społecznego są ubezpieczenia dobrowolne lub fakultatywne kontynuowane. Zgodnie z art. 14 rozporządzenia Parlamentu Europejskiego i Rady nr 883/2004, znowelizowanego rozporządzeniem nr 988/2009, jeżeli zainteresowany na mocy ustawodawstwa państwa członkowskiego podlega ubezpieczeniu obowiązkowemu w tym państwie członkowskim, nie może on podlegać systemowi ubezpieczeń dobrowolnych lub fakultatywnych kontynuowanych w innym państwie członkowskim. We wszystkich innych przypadkach, w których dla danego działu 
ubezpieczenia istnieje wybór pomiędzy kilkoma systemami ubezpieczeń dobrowolnych lub fakultatywnych kontynuowanych, ubezpieczający się może przystąpić do wybranego przez siebie systemu. W odniesieniu do świadczeń z tytułu inwalidztwa, emerytur i rent rodzinnych, zainteresowana osoba może przystąpić do systemu ubezpieczeń dobrowolnych lub fakultatywnych kontynuowanych danego państwa członkowskiego nawet wówczas, gdy obligatoryjnie podlega ustawodawstwu innego państwa członkowskiego, pod warunkiem, że na pewnym etapie swojej pracy zawodowej podlegała ustawodawstwu pierwszego państwa członkowskiego w związku z wykonywaną pracą najemną lub pracą na własny rachunek, oraz jeżeli takie nakładanie się praw jest dozwolone na podstawie ustawodawstwa pierwszego państwa członkowskiego. W sytuacji, gdy ustawodawstwo państwa członkowskiego uzależnia przyjęcie do ubezpieczenia dobrowolnego lub fakultatywnego kontynuowanego od zamieszkania w tym państwie lub od wykonywania wcześniej pracy najemnej albo pracy na własny rachunek, stosuje się zasadę równego traktowania świadczeń, dochodów, okoliczności lub zdarzeń tylko do osób, które podlegały, na jakimś wcześniejszym etapie, ustawodawstwu tego państwa członkowskiego na podstawie pracy najemnej lub pracy na własny rachunek.

Niezwykle ważnej problematyce emerytur i rent rodzinnych poświęcony został rozdział piąty wymienionego wyżej rozporządzenia. W odniesieniu do tej dziedziny prawo unijne wprowadza przepisy dotyczące sumowania okresów ubezpieczenia; przyznawania i ustalania wysokości świadczeń; zasady przeciwdziałania kumulacji świadczeń i zbiegu świadczeń tego samego rodzaju i różnego rodzaju oraz przepisy dodatkowe dotyczące wyliczania świadczeń.

Art. 51 omawianego rozporządzenia Parlamentu Europejskiego i Rady (UE) nr 883/2004 ze zmianami wprowadzonymi rozporządzeniem Parlamentu Europejskiego i Rady nr 988/2004 stanowi, iż okresy ubezpieczenia spełnione na podstawie szczególnego systemu danego państwa członkowskiego są uwzględniane w celu udzielenia świadczeń w ramach systemu ogólnego tego państwa lub innego państwa członkowskiego pod warunkiem, że zainteresowany przystąpił do jednego 
z tych systemów. Jeżeli ustawodawstwo państwa członkowskiego uzależnia przyznanie pewnych świadczeń od spełnienia okresów ubezpieczenia wyłącznie w odniesieniu do określonej pracy najemnej lub na własny rachunek lub w zawodzie, który podlega szczególnemu systemowi dotyczącemu osób zatrudnionych lub pracujących na własny rachunek, właściwa instytucja tego państwa członkowskiego musi uwzględnić okresy spełnione na podstawie regulacji prawnych pozostałych państw członkowskich tylko wtedy, gdy zostały one spełnione na podstawie podobnego systemu.

Ponadnarodowe reguły w zakresie przyznawania świadczeń mówią o tym, że właściwa instytucja ustala wysokość należnych świadczeń według regulacji prawnych stosowanych w przypadkach, gdy warunki uprawniające do świadczeń zostały spełnione wyłącznie na mocy prawa krajowego (świadczenie niezależne). Obliczenie wysokości świadczenia jest również możliwe poprzez ustalenie teoretycznej kwoty świadczenia, a następnie kwoty rzeczywistej (świadczenie proporcjonalne) w następujący sposób: teoretyczna kwota świadczenia jest równa świadczeniu, o które zainteresowany mógłby się ubiegać, gdyby wszystkie okresy ubezpieczenia uwzględnione na mocy ustawodawstw pozostałych państw członkowskich zostały zakończone na podstawie ustawodawstwa, które jest stosowane w dniu przyznania świadczenia. Jeżeli zgodnie z tym ustawodawstwem kwota świadczenia nie zależy od długości okresów ubezpieczenia, kwota świadczenia zostaje uznana za kwotę teoretyczną. Następnie jest ustalana rzeczywista kwota świadczenia proporcjonalnego poprzez doliczenie do kwoty teoretycznej stosunku długości okresów ubezpieczenia ukończonych przed realizacją ryzyka ujętego w danym ustawodawstwie do całkowitej długości okresów ubezpieczenia ukończonych przed wystąpieniem określonego ryzyka zgodnie z regulacjami wszystkich zainteresowanych państw członkowskich.

Zainteresowany ubiegający się o przyznanie świadczenia jest uprawniony do otrzymania od właściwej instytucji każdego państwa członkowskiego wyższej kwoty świadczenia od kwot ustalanych zgodnie z wyżej wymienionymi przepisami. 


\section{Zasada przeciwdziałania kumulacji świadczeń (proporcjonalności)}

W ramach koordynacji zabezpieczenia społecznego w UE znaczącą pozycję zajmują zasady przeciwdziałania kumulacji świadczeń z tytułu inwalidztwa, starości i rent rodzinnych. Rozporządzenia Parlamentu Europejskiego i Rady (UE) nr 883/2004 i nr 988/2009 mówią o przeciwdziałaniu kumulacji świadczeń różnego rodzaju i zbiegu świadczeń tego samego rodzaju. Za kumulację świadczeń tego samego rodzaju jest uważana kumulacja świadczeń z tytułu inwalidztwa, z tytułu starości i rent rodzinnych. W celu stosowania zasad przeciwdziałania kumulacji określonych świadczeń przez ustawodawstwo państwa członkowskiego z tytułu inwalidztwa, starości lub renty rodzinnej ze świadczeniem tego samego rodzaju lub ze świadczeniem różnego rodzaju, właściwa instytucja na mocy art. 53 wyżej wymienionego rozporządzenia:

- bierze pod uwagę świadczenia lub dochody uzyskane w innym państwie członkowskim tylko wtedy, gdy stosowane przez nią ustawodawstwo przewiduje uwzględnienie świadczeń lub dochodów uzyskanych za granicą,

- uwzględnia wysokość świadczeń, jakie mają być wypłacane przez inne państwo członkowskie przed potrąceniem podatków, składek z tytułu ubezpieczenia społecznego i innych opłat i potrąceń indywidualnych, jeżeli stosowane przez nią ustawodawstwo nie przewiduje zasad przeciwdziałania kumulacji po dokonaniu takich potrąceń na warunkach i zgodnie z procedurami przewidzianymi w rozporządzeniu wykonawczym,

- nie uwzględni wysokości świadczeń uzyskanych zgodnie z ustawodawstwem innego państwa członkowskiego na podstawie ubezpieczenia dobrowolnego lub fakultatywnego kontynuowanego,

- jeżeli dane państwo członkowskie stosuje zasady przeciwdziałania kumulacji, ponieważ zainteresowany otrzymuje świadczenia tego samego rodzaju lub innego rodzaju na podstawie ustawodawstwa innego państwa członkowskiego lub dochód uzyskany w innych 
państwach członkowskich, należne świadczenie może być obniżone wyłącznie o kwotę takich świadczeń lub takiego dochodu.

W przypadkach zbiegu świadczeń tego samego rodzaju na podstawie ustawodawstwa dwóch lub więcej państw członkowskich zasady przeciwdziałania kumulacji określone przez przepisy danego państwa członkowskiego nie mają zastosowania do świadczenia proporcjonalnego. Zasady zapobiegania kumulacji są stosowane $\mathrm{w}$ odniesieniu do świadczenia niezależnego wówczas, gdy dane świadczenie jest: świadczeniem, którego kwota nie zależy od długości okresów ubezpieczenia lub zamieszkania, albo świadczeniem, którego kwota jest ustalana na podstawie zaliczonego okresu uważanego za spełniony pomiędzy dniem wystąpienia ryzyka a terminem późniejszym, zbiegającym się ze świadczeniem tego samego rodzaju lub ze świadczeniem, którego kwota nie zależy od długości okresów ubezpieczenia lub zamieszkania.

Prawo UE zawiera odrębne regulacje odnoszące się do przeciwdziałania kumulacji świadczeń różnego rodzaju. W przypadku wystąpienia dwóch lub więcej niezależnych świadczeń właściwe instytucje podzielą kwoty świadczeń, czy też innych dochodów, przez liczbę świadczeń podlegających wspomnianym zasadom. To postępowanie nie może jednak pozbawić zainteresowanego jego statusu emeryta lub rencisty. W sytuacji zbiegu jednego lub więcej świadczeń proporcjonalnych przy obliczaniu kwoty świadczenia właściwe instytucje biorą pod uwagę świadczenie lub świadczenia oraz inne dochody do wyliczenia kwoty świadczenia proporcjonalnego. Właściwa instytucja nie stosuje powyższego podziału w odniesieniu do świadczeń niezależnych, jeżeli regulacje prawne, na podstawie których działa, przewidują uwzględnianie świadczeń różnego rodzaju.

\section{Zasada pierwszeństwa w przypadku zbiegu praw do świadczeń}

Kolejnymi istotnymi zasadami koordynacji zabezpieczenia społecznego w UE są zasady pierwszeństwa w przypadku zbiegu praw do świadczeń. Reguluje je art. 68 rozporządzenia Parlamentu Europejskiego i Rady (UE) nr 883/2004 ze zmianami wprowadzonymi rozporządzeniem nr 988/2009. 
Jeżeli na podstawie ustawodawstwa więcej niż jednego państwa członkowskiego udzielane są świadczenia przez więcej niż jedno państwo członkowskie z różnych tytułów, obowiązuje następująca kolejność: w pierwszej kolejności są uwzględniane prawa z tytułu zatrudnienia lub pracy na własny rachunek, w drugiej kolejności prawa do otrzymywania emerytury lub renty i w ostatniej kolejności prawa uzyskiwane na podstawie miejsca zamieszkania. W przypadku świadczeń wypłacanych przez więcej niż jedno państwo członkowskie z tego samego tytułu, kolejność pierwszeństwa jest ustalana w oparciu o dodatkowe kryteria. W odniesieniu do świadczeń uzyskiwanych z tytułu zatrudnienia lub pracy na własny rachunek takim kryterium jest miejsce zamieszkania dzieci. W stosunku do osób otrzymujących emerytury lub renty takim kryterium jest miejsce zamieszkania dzieci i dodatkowo najdłuższy okres ubezpieczenia lub zamieszkania. Jeżeli ubezpieczony uzyskuje świadczenia na podstawie miejsca zamieszkania, stosuje się jako dodatkowe kryterium miejsce zamieszkania dzieci. Zbieg uprawnień do świadczeń rodzinnych jest rozstrzygający w oparciu o wyżej wymienione kryteria.

\section{Regulacje prawa unijnego dotyczące składek na ubezpieczenia społeczne}

Prawo unijne nie zawiera natomiast przepisów określających zasady ustalania wysokości składek na ubezpieczenie społeczne. W tym zakresie mają zastosowanie regulacje prawne danego państwa członkowskiego, w którym zainteresowany podlega obowiązkowemu ubezpieczeniu. Jednakże w unormowaniach unijnych dotyczących koordynacji zabezpieczenia społecznego występuje pojęcie składki na ubezpieczenie społeczne. Mowa jest o niej w art. 56 rozporządzenia Parlamentu Europejskiego i Rady nr 883/2004 ze zmianami wprowadzonymi rozporządzeniem nr 988/2009, który zawiera przepisy dodatkowe dotyczące wyliczenia składek. Jednak ust. 1 lit. c nawiązuje do regulacji przyjętych przez ustawodawcę narodowego, przyznając uprawnienia właściwej instytucji do wyliczenia składek, jeżeli ustawodawstwo danego państwa członkowskiego stanowi, że świadczenia mają być wyliczane na podstawie 
dochodów, składek, podstaw składek, podwyżek, zarobków, innych kwot lub kombinacji powyższych elementów (średnich, proporcjonalnych, zryczałtowanych lub zaliczonych), to wówczas wspomniana instytucja:

- określa podstawę ustalania świadczeń, biorąc pod uwagę wyłącznie okresy ubezpieczenia ukończone na mocy stosowanego przez nią ustawodawstwa,

- $\quad$ wykorzystuje w celu określenia kwoty wyliczonej na podstawie okresów ubezpieczenia czy też zamieszkania spełnionych zgodnie z ustawodawstwem pozostałych państw członkowskich, te same składniki określone dla ukończonych okresów ubezpieczenia i ujęte w ramach stosowanego przez nią ustawodawstwa.

Według art. 56 ust. 1 lit. d w przypadku, gdy ustawodawstwo państwa członkowskiego stanowi, że świadczenie ma być wyliczane przy zastosowaniu elementów innych niż okresy ubezpieczenia lub zamieszkania, które nie są związane z czasem, odpowiednia instytucja uwzględnia $\mathrm{w}$ odniesieniu do każdego $\mathrm{z}$ okresów ubezpieczenia lub zamieszkania ukończonych zgodnie z przepisami jakiegokolwiek innego państwa członkowskiego - kwotę zgromadzonego kapitału, kwotę kapitału uznawanego za zgromadzony lub jakikolwiek inny element stosowany przy wyliczaniu $\mathrm{w}$ danym państwie, podzielony przez odpowiadające im jednostki okresów w danym systemie emerytalnorentowym.

Natomiast art. 7 rozporządzenia Parlamentu Europejskiego i Rady nr 987/2009 z dnia 16 września 2009 r. ${ }^{6}$ mówi o obowiązku zapłacenia składki. Pojęcie składek na ubezpieczenie pojawia się też w art. 73 tegoż rozporządzenia regulującego zagadnienie tymczasowo wypłacanych świadczeń pieniężnych lub składek. Zgodnie z ust. 2 art. 73 instytucja, która tymczasowo otrzymywała składki, ma obowiązek zwrócić te kwoty osobom, które je zapłaciły, dopiero po otrzymaniu od instytucji uznanej za właściwą potwierdzenia w odniesieniu do kwot jej należnych. Na wniosek

6 Rozporządzenie Parlamentu Europejskiego i Rady (WE) nr 987/2009 z dnia 16 września 2009 r. dotyczące wykonywania rozporządzenia (WE) nr 883/2004 w sprawie koordynacji systemów zabezpieczenia społecznego (Dz.Urz. UE L Nr 284 z 30 października 2009 r.). 
instytucji uznanej za właściwą instytucja, która tymczasowo otrzymywała składki, przekazuje je instytucji uznanej za właściwą dla tego samego okresu, która ma następnie za zadanie ocenić sytuację zainteresowanego w zakresie składek. Przekazane składki są przyjmowane z mocą wsteczną i uznawane za spłacone na rzecz instytucji właściwej. Jeżeli kwota tymczasowo opłaconych składek jest wyższa niż kwota należna instytucji właściwej, instytucja, która tymczasowo otrzymywała składki, zwraca nadpłacona kwotę zainteresowanej osobie.

\section{Podsumowanie}

Podsumowując omawianie wybranych zagadnień związanych z koordynacją zabezpieczenia społecznego w UE, można powołać się na zdanie Parlamentu Europejskiego i Rady UE zawarte w uzasadnieniu do rozporządzenia nr 883/2004 mówiące o tym, że środki koordynujące mają zagwarantować prawo do swobodnego przepływu osób, a taki cel nie może być w pełni zrealizowany przez państwa członkowskie i osiągnięty może być dopiero na poziomie Wspólnoty. Środki służące osiągnięciu tego celu Wspólnota przyjmuje zgodnie z zasadą pomocniczości. Regulacje prawa unijnego dotyczące składek na ubezpieczenie społeczne również stanowią rozstrzygnięcie pewnych kwestii o charakterze ponadnarodowym. Nie zastępują w tej dziedzinie ustawodawstwa krajowego, a jedynie je uzupełniają w celu zapewnienia skuteczniejszej współpracy pomiędzy instytucjami zajmującymi się zabezpieczeniem społecznym.

\section{Bibliografia:}

Dzienisiuk D., Zabezpieczenie społeczne w Unii Europejskiej - koordynacja świadczeń, Difin, Warszawa 2004.

Major T. (red.), Pawłowska B., Ubezpieczenie społeczne migrujących pracowników oraz osób prowadzq̨cych działalność gospodarczq, C.H. Beck, Warszawa 2004.

Przepisy UE w dziedzinie zabezpieczenia społecznego. Twoje prawa w innych państwach Unii Europejskiej, Urząd Publikacji Unii Europejskiej, Luksemburg 2010. 
Alicja Młynarczyk

Uścińska G., Kierunki rozwoju świadczeń z zabezpieczenia społecznego na przykładzie wspólnotowej koordynacji [w:] A. Patulski, K. Walczak (red.), Jedność w różnorodności. Studia z zakresu prawa pracy, zabezpieczenia społecznego i polityki społecznej. Księga pamiq̨tkowa dedykowana profesorowi Wojciechowi Muszalskiemu, C.H. Beck, Warszawa 2009.

Wantoch-Rekowski J., System ubezpieczeń społecznych a budżet państwa. Studium prawnofinansowe, Wolters Kluwer, Warszawa 2014. 